\title{
Application of "One Teacher, One Excellent Course" in Digital Electronic Technology Teaching
}

\author{
Ting Zhang ${ }^{\mathrm{a}}$, Zuliang Wang ${ }^{\mathrm{b}}$ and Yun Shic \\ Department of Information Engineering, Xijing University, Xi'an, 710123, China \\ a1046935520@qq.com, b1601252678@qq.com, ${ }^{\mathrm{c}} 741725347 @ q q . c o m$
}

\begin{abstract}
Keywords: One teacher; one excellent course; Digital electronic course; Composition structure; Teaching effect
\end{abstract}

\begin{abstract}
One Teacher, One Excellent Course" has a positive effect on the establishment of high-quality educational resources for the country and local governments, and the effective application and deep integration of information technology and digital educational resources. In order to improve the quality of teaching, Xijing University encourages teachers to establish " One teacher, one excellent course ". Taking the course of digital electronic technology as an example, this paper expounds the composition structure of "one teacher and one excellent course" of digital circuit technology, analyzes on the importance of "one teacher and one excellent course" in College teaching, and probes into how to make better use of the excellent course to improve teaching effect.
\end{abstract}

\section{Introduction}

"One Teacher and One Excellent Course" is an activity launched by the Ministry of Education in 2014, aiming at deepening the curriculum reform in an all-round way and "constructing an effective mechanism to expand the coverage of high-quality educational resources by means of information technology". Through excellent courses, every teacher should be able to use information technology to teach at least one lesson, so that at least one excellent teacher can use information technology to teach each lesson. Enhance the understanding of teachers of the importance of information technology to promote teaching reform and improve teaching quality, and fully mobilize the enthusiasm and creativity of teachers in all disciplines in the application of information technology in classroom teaching. From the student's point of view, from the result assessment to the process assessment, pay attention to the learning process, promote students' learning enthusiasm. So that teaching and learning can be effectively integrated, and ultimately the quality of teaching is improved.

\section{The Composition of Digital Electronic Technology "One Teacher, One Excellent Course"}

"One Teacher, One Excellent Course" of Xijing University mainly consists of content module, examination, forum, knowledge architecture, curriculum, documents and other modules. Here we can upload the syllabus, teaching plan, experiment guide book and so on. The composition of digital electronic technology "One Teacher, One Excellent Course" is shown in figure 1. The content module is divided into six parts: project section, design circuit by Multisim software + verification demonstration section, practice training + student explanation section, teacher classroom recording section, student classroom recording section and assignment list. The composition of content module is shown in figure 2. 


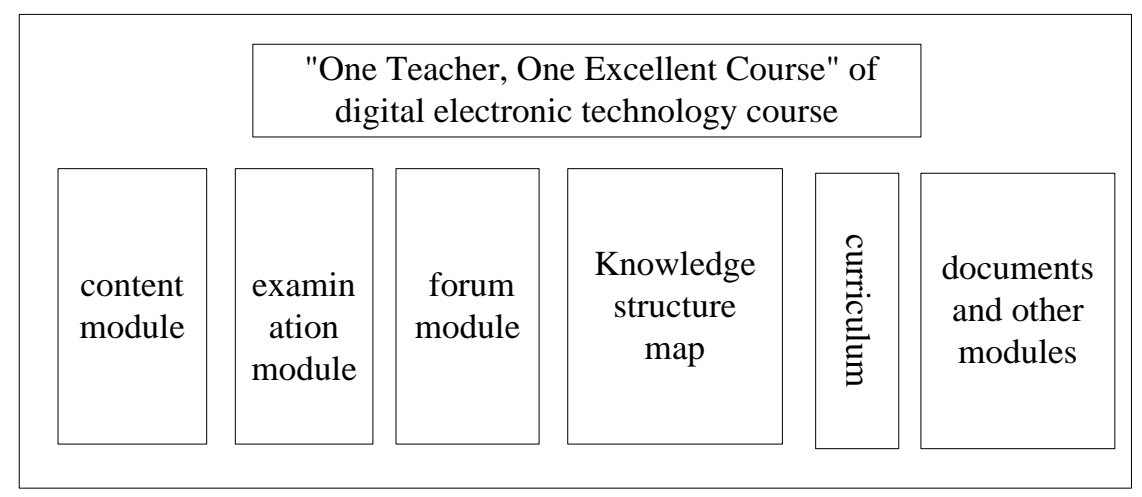

Figure 1. The composition of digital electronic technology "One Teacher, One Excellent Course"

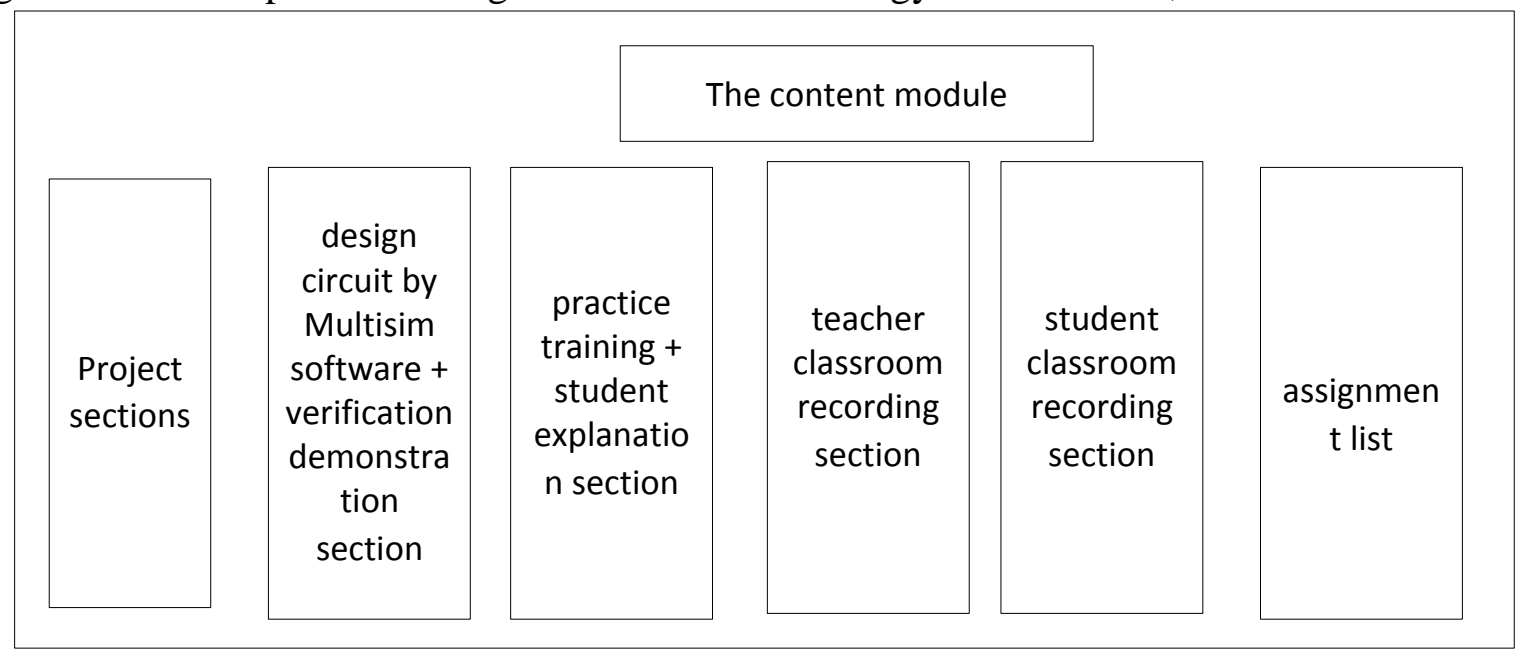

Figure 2. The composition of content module

Project sections include courseware, lesson plans, micro-videos and typical exercises. Micro-videos help students understand key and difficult points. Design Circuit by Multisim Software + Verification Demo includes the circuit designed by students, and it is simulated and demonstrated with Multisim software. Practice training + students' explanations are practical training, including the process of designing circuit, and the explanation of circuit working principle. These two parts can only be achieved on the basis of students' good grasp of the knowledge. Designing circuits and analyzing them by themselves can improve students' ability to analyze, design and solve problems. The student's classroom recording is a part of the flipped classroom, recording the process of students' understanding and explanation of knowledge, encouraging students to put forward their own views, and training their thinking ability. Homework lists include excellent assignments and excellent experimental reports, encouraging students to do their homework best and improving the quality of homework, which can not only rectify students' learning attitude, also can stimulate students' desire to participate, so that students can find the motivation of independent learning in the results show. The examination module is divided into the fixed examination paper and the free examination paper. Students can take the online examination and refer to the correct answers. Students can practice the questions early and grasp the knowledge points in time. At the same time, students and teachers can communicate with each other in the forum module at any time, which can improve the chance of the participation of students in learning.

\section{The Importance of "One Teacher, One Excellent Course"}

In order to construct "one teacher and one excellent course", teachers need to reorganize the training objectives, framework system, the internal links between chapters, the key and difficult parts of the course, and the learning effects required of students in each part. It is helpful for teachers to further 
understand the curriculum, form a new framework and clear goals, and improve the quality of classroom teaching. For each chapter, project key and difficult knowledge, teachers can upload through micro-video, and students can play unlimited number of times, which helps students understand knowledge, while save a lot of time for teachers. Also teachers can learn from each other to exchange, evaluate, and generally improve the quality of classroom teaching.

With the application of "one teacher and one excellent course", students can explore independently, cooperate with each other and study individually to stimulate their enthusiasm for learning. Pre-class preview is targeted, and class with questions to listen to the lecture, after class the knowledge points not understood can be repeated by playing micro-video, courseware. Every part of the content can be tested after learning, stage to complete the test, which can consolidate knowledge early, avoid the end of the semester review intensity of the phenomenon. It realizes the learning vision of "everyone learns, everywhere learns, and learns from time to time". At the same time, you can leave a message to discuss problems, and you can join in and think together to solve the problem.

In short, teachers and students have changed their roles. Teachers change from the center of teaching to the partners, organizers and guides of students. Students turn from passive recipients to masters of learning. Effective training of students to explore, unite and cooperate, solve problems.

\section{How to Make Better Use of "One Teacher, One Excellent Course"}

At this stage, the construction process of "one teacher, one excellent course" is basically completed. In practical application, most students are passive learning under the strong demand of teachers, even some students just brush time and do not read the content, which lose the meaning and original intention of the network course.

Therefore, in order to solve such problems and really play the role of "one teacher, one excellent course", the following suggestions are put forward. First, Combine flipped classroom with "one teacher, one excellent course" effectively, the resources of "one teacher, one excellent course" provide practical and theoretical basis and material resources for "flipped classroom", making it an important carrier of pre-class preview. Then go back to the classroom, discuss the relevant content and complete the homework, promote students' independent development and cooperative participation, in classroom teachers supplement, answer questions. Second: Adding the effect of excellent lessons to students' normal grades, in classroom, teachers can examine students' learning results through simple tests and stimulate students' autonomous learning. Third: Examination questions come from the network course, in colleges and universities, some students have such a mentality, usually do not listen to lectures, but wait for the teacher to outline in the end of the semester, through the pre-test sprint, and ultimately pass the exam. We should strictly put an end to this phenomenon. Examination questions come from the questions in the "one teacher, one excellent course" test paper module, and urge students to practice exercises independently. At the same time, they can refer to the correct answers for the wrong questions. It is a mean to pay attention to the usual learning process, cultivate students' good learning habits, and truly achieve the purpose of practice.

\section{Conclusions}

"One Teacher, One Excellent Course" puts forward higher requirements for teachers, and the teaching level of teachers must be improved. It saves teachers' energy and promotes teachers' professional development. At the same time, it helps students to study conveniently, change the result assessment to the process assessment, and emphasize the importance of the learning process. Therefore, in today's information society, the rational and effective use of "one teacher and one excellent" resources is of great significance. In order to enable students and teachers to better apply "one teacher, one excellent course" to teaching and learning, we need to constantly explore and optimize continuously. 


\section{References}

[1] Zhang Guoyu. Reform and Practice of Digital Electronic Technology Experiment Teaching [J].Experimental Science and Technology, 2018,16(02): 153-156.

[2] Xie Meng, Wang Juan. Application of Micro-course in Digital Electronic Technology Experiment Teaching in Independent Colleges [J].Laboratory Research and Exploration, 2018,37(03): 218-221.

[3] Feng Hao. Exploratory Research on Digital Electronic Technology Experimental Teaching in Higher Vocational Colleges [J].Science and Technology Information, 2016,14 (35): 189+191.

[4] Han Xinfeng, Gao Haitao, Li Yong. Application of Project Teaching Method in the Teaching of Digital Electronic Technology [J].Education Modernization, 2018,5(27): 252-254.

[5] Yang Xuemei, Shen Yibin. Research, Reform and Practice of Digital Electronic Technology and Experimental Teaching [J].Education Modernization, 2016,3 (38): 99-100.

[6] Zhang Tianpeng, Zhang Weiwei, Hou Jun.Reform and Exploration of Digital Electronic Technology Experiment Teaching[J].Journal of Anyang Institute of Technology, 2016,15 (04): 106-108.

[7] Zhao Fangzhen, Liang Haiying, Zhu Sisi, Chen Guanping. Teaching reform and practice of digital electronic technology course for Internet of Things major [J].Computer Knowledge and Technology, 2016,12(06): 265-266+268.

[8] Ma Huilan. Reflections on the Teaching Reform of Digital Electronic Technology Experiment [J]. Management and Technology for Small and Medium-sized Enterprises (later issue), 2016 (01): 196-197.

[9] Zhang Ke Ju, Peng Kai Feng. Digital electronic technology experiment teaching reform research [J]. electronic production, 2013 (20): 142.

[10] Ning Guidi, Jin Yinbin, Liu Tao, Yang Shuang. [J].Journal of Electrical and Electronic Education, 2013, 35 (04): 102-103.

[11] Yang Fang. An Analysis of the Role of "One Teacher and One Excellent Course" in "English Flip Classroom"[J].Reading and Writing (Educational Journal), 2017,14 (10): 100.

[12] Kang Xin Xin. Interactive research on fine arts classroom teaching in primary schools based on video analysis [D]. Shaanxi Normal University, 2017.

[13] Wang Junqing. Use the activity of "one teacher, one excellent course, one teacher" to improve teachers'information literacy [J].Tibetan Education, 2017 (03): 62-64.

[14] $\mathrm{Hu}$ Shanshan. Research on the actuality and strategy of "one teacher, one excellent course, one teacher" activity [D]. Huanggang Normal University, 2018.

[15] Wang Junqing. Use the activity of "one teacher, one excellent course, one teacher" to improve teachers'information literacy [J].Tibetan Education, 2017 (03): 62-64. 